\title{
Auditory brainstem response in neonates: influence of gender and weight/gestational age ratio
}

\author{
Potencial evocado auditivo de tronco encefálico em recém-nascido: influência do sexo e da relação \\ peso e idade gestacional
}

Potencial evocado auditivo de tronco encefálico en recién nacidos: influencia del sexo y de la relación peso y edad gestacional

Rosanna M. Giaffredo Angrisani ${ }^{1}$, Ana Paula D. Bautzer ${ }^{1}$, Carla Gentile Matas ${ }^{2}$, Marisa Frasson de Azevedo ${ }^{3}$

\section{ABSTRACT}

Objective: To investigate the influence of gender and weight/gestational age ratio on the Auditory Brainstem Response (ABR) in preterm (PT) and term (T) newborns.

Methods: 176 newborns were evaluated by ABR; 88 were preterm infants - 44 females ( 22 small and 22 appropriate for gestational age) and 44 males (22 small and 22 appropriate for gestational age). The preterm infants were compared to 88 term infants - 44 females (22 small and 22 appropriate for gestational age) and 44 males (22 small and 22 appropriate for gestational age). All newborns had bilateral presence of transient otoacoustic emissions and type A tympanometry.

Results: No interaural differences were found. ABR response did not differentiate newborns regarding weight/gestational age in males and females. Term newborn females showed statistically shorter absolute latencies (except on wave I) than males. This finding did not occur in preterm infants, who had longer latencies than term newborns, regardless of gender.

Conclusions: Gender and gestational age influence term infants' ABR, with lower responses in females. The weight/ gestational age ratio did not influence $A B R$ response in either groups.

Key-words: evoked potentials, auditory, brain stem; auditory perception; hearing disorders; infant, newborn.

\section{RESUMO}

Objetivo: Verificar as influências do sexo e a relação peso/idade gestacional nas respostas do Potencial Evocado Auditivo de Tronco Encefálico (PEATE) em recém-nascidos pré-termo (PT) e a termo (T).

Métodos: Avaliaram-se 176 recém-nascidos por meio do PEATE, sendo 88 prematuros - 44 femininos (22 pequenos e 22 adequados para a idade gestacional) e 44 masculinos (22 pequenos e 22 adequados para a idade gestacional). Compararam-se os prematuros a 88 recém-nascidos a termo, 44 do sexo feminino (22 pequenos e 22 adequados) e 44 do sexo masculino (22 pequenos e 22 adequados). Todos os recém-nascidos apresentaram emissões otoacústicas bilateralmente, por estímulo transiente e timpanometria tipo A.

Resultados: Não se encontraram diferenças interaurais e no desempenho dos recém-nascidos nas respostas do PEATE quanto à classificação peso/idade gestacional, em ambos os sexos. Os recém-nascidos a termo do sexo feminino mostraram latências absolutas estatisticamente mais curtas (exceto onda I) do que os do masculino; o mesmo não ocorreu nos prematuros. Os neonatos pré-termo apresentaram latências mais prolongadas que as dos recém-nascidos a termo, independentemente do sexo.

Conclusões: $O$ sexo e a idade gestacional exercem influência relevante no PEATE de recém-nascidos a termo,
Instituição: Hospital São Paulo da Universidade Federal de São Paulo (Unifesp), São Paulo, SP, Brasil

${ }^{1}$ Hospital São Paulo da Unifesp, São Paulo, SP, Brasil

${ }^{2}$ Faculdade de Medicina da Universidade de São Paulo (USP), São Paulo, SP, Brasil

${ }^{3}$ Escola Paulista de Medicina da Unifesp, São Paulo, SP, Brasil
Endereço para correspondência:

Rosanna M. Giaffredo Angrisani

Rua Botucatu, 802 - Vila Clementino

CEP 04023-062 - São Paulo/SP

E-mail: roangrisani@gmail.com

Conflito de interesse: nada a declarar 
com respostas menores no sexo feminino. A relação peso/ idade gestacional, ao contrário, não interfere nas respostas desse potencial.

Palavras-chave: potenciais evocados auditivos do tronco encefálico; percepção auditiva; transtornos da audição; recém-nascido.

\section{RESUMEN}

Objetivo: Verificar las influencias del sexo y la relación peso/edad gestacional en las respuestas del Potencial Evocado Auditivo de Tronco Encefálico (PEATE) en recién nacidos pretérmino (PT) y a término (T).

Métodos: Se evaluaron a 176 recién nacidos por medio del PEATE, siendo 88 prematuros - 44 femeninos (22 pequeños y 22 adecuados para la edad gestacional) y 44 masculinos (22 pequeños y 22 adecuados para la edad gestacional). Se compararon los prematuros con 88 recién nacidos a término, 44 del sexo femenino (22 pequeños y 22 adecuados) y 44 del sexo masculino (22 pequeños y 22 adecuados). Todos los recién nacidos presentaron emisiones otoacústicas bilateralmente, por estímulo transiente y timpanometría tipo A.

Resultados: No se encontraron diferencias interaurales y en el desempeño de los recién nacidos en las respuestas del PEATE respecto a la clasificación peso/edad gestacional, en ambos sexos. Los recién nacidos a término del sexo femenino mostraron latencias absolutas estadísticamente más cortas (excepto onda I) que las del sexo masculino; lo mismo no pasó con los prematuros. Los neonatos pretérmino presentaron latencias más prolongadas que las de los recién nacidos a término, independiente del sexo.

Conclusiones: El sexo y la edad gestacional ejercen influencia relevante en el PEATE de recién nacidos a término, con respuestas menores en el sexo femenino, debiendo considerárselas en el análisis clínico. La relación peso/edad gestacional, en contrario, no interfiere en las respuestas de ese potencial.

Palabras clave: potenciales evocados auditivos del tronco encefálico; percepción auditiva; trastornos de la audición; recién nacido.

\section{Introduction}

Because it represents an indicator of intrauterine growth restriction and, therefore, an example of early malnutrition ${ }^{(1)}$, the condition of being small for gestational age (SGA) may lead infants to present changes in their neuropsychomotor development, including hearing and language in this context ${ }^{(2,3)}$.

From an anthropometric perspective, the SGA newborn has a birth weight below the 10th percentile on the fetal growth curve, which relates birth weight and gestational age ${ }^{(4)}$.

The literature emphasizes the fact that SGA newborns, both term and preterm, may evolve with impairment of their neurobehavioral, motor, visual, hearing, and language skills, among others, as a consequence of a delayed neurological maturation ${ }^{(5-7)}$. Some authors report that the results of the Auditory Brainstem Response (ABR) test are influenced by the auditory maturation, whose characteristics differ between term and preterm children, due to myelination of fibers of the auditory pathway in the caudal-rostral direction ${ }^{(8-10)}$.

The ABR is considered the gold standard in the diagnosis of the integrity of the auditory nerve and the auditory pathways of the central nervous system in neonates, besides allowing the assessment and monitoring of the maturation process of this pathway throughout the brainstem $^{(11)}$. In the literature, there are few studies that seek to determine the influence of sex on the results of the ABR in newborns. The results are conflicting, because while some authors conclude that there are important differences between the sexes, others suggest that such differences, because they are small, have no relevant clinical expression ${ }^{(12-16)}$.

From the exposed arguments, plus the fact that the population of SGA newborns is a very heterogeneous group, as it might have suffered injuries at different times during intrauterine life and presents an also varied auditory behavior ${ }^{(7,16)}$, came the need to investigate the influence of sex and weight/ gestational age in ABR responses. Thus, the present study examined the influence of the variables gender and weight/ gestational age ratio in the ABR responses in preterm (PT) and term $(\mathrm{T})$ infants.

\section{Method}

After approval by the Research Ethics Committee of Universidade Federal de São Paulo (Unifesp), mothers and/or caregivers who agreed to the participation of their newborns in the research signed an informed consent, according to Resolution 196/96.

The sample consisted of infants admitted to the nursery of Hospital São Paulo, University Hospital of Unifesp, in the period from December 2011 and June 2012. 
The infants were considered preterm for gestational age of up to 36 weeks and 6 days, according to the World Health Organization ${ }^{(17)}$. For gestational age from 37-40 weeks, the infants were classified as term newborns. Gestational age was defined according to the last menstrual period, confirmed by ultrasound in the first trimester of pregnancy. Infants with birth weights between the 10th and the 90th percentiles were classified as appropriate for gestational age (AGA), and newborns with weight below the 10th percentile as small for gestational age (SGA), according to the reference curve of fetal growth adopted in the institution ${ }^{(4)}$.

The eligibility criteria were the presence of the indicators small for gestation age (SGA group) and appropriate for gestational age (AGA group), bilateral presence of transient evoked otoacoustic emissions (TEOAE) and tympanometry type $\mathrm{A}^{(18)}$ for all groups. The newborns who presented infectious risk for toxoplasmosis, rubella, cytomegalovirus, herpes, and syphilis as well as those with suspicion of encephalopathy, craniofacial malformations, or conductive and/or cochlear changes were excluded from the sample.

Initially, we evaluated the medical records of newborns to collect data according to the eligibility criteria of the sample for anthropometric measurements and gestational age. The newborns selected by the proposed criteria were tested in the following order: inspection of the external auditory canal to visualize tympanic membrane with otoscope (Welch Allyn), TEOAE test, and acoustic immittance measures (tympanometry), to ensure integrity of the cochlear function and the absence of middle ear involvement, respectively. We used the AccuscreenPRO automatic portable equipment (GN Otometrics ${ }^{\circledR}$ ). To obtain "pass" in the register of the EOAE, the equipment was calibrated by the manufacturer to automatically analyze the answers with the following parameters: method of evaluation by binomial statistical; nonlinear click stimulus in sequence with speed of $60 \mathrm{~Hz}$ and intensity of 70-84dB SPL (45-60dBHL, with calibration depending on the volume in the ear canal); frequency spectrum from 1.4 to $4 \mathrm{kHz}$; artifact lower than $20 \%$. When these parameters were obtained, the equipment registered "pass".

The acoustic impedance measures covered tympanometry with $1 \mathrm{kHz}$ tone probe, held by middle ear analyzer (Interacoustics, model AT 235-H).

To perform the ABR, the child remained in natural sleep in the crib or in his or her mother's lap. To capture this potential, we used the clinical/diagnostic equipment model Smart-EP (Intelligent Hearing Systems ${ }^{\circledR}$ ). The preparation of all newborns for ABR testing occurred as follows: precleaning of the skin with abrasive paste and attachment of the pediatric disposable electrodes Meditrace-200 (Kendal), in the frontal region $(\mathrm{Fpz})$ and in the right and left mastoids $\left(\mathrm{M}_{2}\right.$ e $\left.\mathrm{M}_{1}\right)$, according to the norm by the International Electrode System (IES 10-20) ${ }^{(19)}$. The acoustic stimulus was presented by a pair of insert earphones ER-3A, eliciting responses. The impedance of the electrodes remained lower than $3 \mathrm{k} \Omega$. The acoustic stimulus used was the rarefaction polarity click, monaurally presented at $80 \mathrm{dBnNA}$ for assessing auditory pathway integrity, in presentation speed of 27.7 clicks by second, duration of $0.1 \mathrm{~ms}$, high pass filters of $100 \mathrm{~Hz}$ and low pass of $1.500 \mathrm{~Hz}$, totaling 2,048 stimuli. We used a 12-ms recording window. The ABR was captured twice in each ear, in order to obtain wave reproducibility and ensure the presence of response. For the analysis of the ABR responses, absolute latencies of waves I, III, V and the interpeak intervals I-III, III-V, I-V at $80 \mathrm{dBnNA}$ were measured. The results of each assessment were recorded and delivered to the parent or legal guardian.

The statistical analysis consisted initially of data description by means of the averages and standard deviations of each studied group. Then, all measures of right and left ears of each indivdual were compared through the paired Student $t$ test. The comparison of means between the groups was performed by analysis of variance (ANOVA).

A convenience sample was used, with a confidence interval of $95 \%$ and the level of significance was established at $5 \%$.

\section{Results}

The study included 176 newborns, divided as follows: 88 healthy preterm infants ( 44 females and 44 males). Among the 44 female newborns, 22 were SGA and 22, AGA. The preterm newborns (PTNB) were compared to 88 healthy term newborns (TNB), being 44 female and 44 male. Among the 44 female TNBs, 22 were SGA and 22, AGA, with the same composition for males.

In preterm infants, gestational age ranged from 32 weeks and 4 days to 36 weeks and 1 day. Upon examination, the corrected gestational age ranged from 35 weeks and 2 days to 36 weeks and 6 days. The gestational age of the TNBs ranged from 37 to 40 weeks and 5 days, and upon examination, it ranged from 37 weeks and 1 day to 41 weeks and 2 days. The analysis of the ABR parameters performed previously for each ear did not demonstrate relevant interaural 
Table 1 - Comparative study of mean latencies of waves I, III, V and interpeak intervals I-III, III-V, I-V of the Auditory Brainstem Response (ABR) test in term neonates, in both sexes, regarding the adequacy of birth weight

\begin{tabular}{|c|c|c|c|c|c|c|c|c|c|c|}
\hline & \multicolumn{5}{|c|}{ Male/Term } & \multicolumn{5}{|c|}{ Female/Term } \\
\hline & \multicolumn{2}{|c|}{ SGA $(n=44)$} & \multicolumn{2}{|c|}{ AGA $(n=44)$} & \multirow{2}{*}{$p$-value } & \multicolumn{2}{|c|}{ SGA $(n=44)$} & \multicolumn{2}{|c|}{ AGA $(n=44)$} & \multirow{2}{*}{$p$-value } \\
\hline & Mean & SD & Mean & SD & & Mean & SD & Mean & SD & \\
\hline $\mathrm{I}$ & 1.78 & 0.09 & 1.78 & 0.08 & 0.672 & 1.82 & 0.10 & 1.79 & 0.20 & 0.401 \\
\hline III & 4.67 & 0.26 & 4.63 & 0.23 & 0.445 & 4.56 & 0.23 & 4.50 & 0.26 & 0.191 \\
\hline V & 7.10 & 0.38 & 6.99 & 0.21 & 0.113 & 6.86 & 0.23 & 6.78 & 0.22 & 0.253 \\
\hline$|-|||$ & 2.89 & 0.24 & 2.83 & 0.15 & 0.182 & 2.74 & 0.22 & 2.71 & 0.23 & 0.585 \\
\hline III-V & 2.43 & 0.33 & 2.39 & 0.19 & 0.499 & 2.28 & 0.21 & 2.28 & 0.23 & 1.000 \\
\hline $\mathrm{I}-\mathrm{V}$ & 5.31 & 0.38 & 5.15 & 0.49 & 0.080 & 5.02 & 0.27 & 5.00 & 0.23 & 0.752 \\
\hline
\end{tabular}

SGA: small for gestational age; AGA: appropriate for gestational age; SD: standard-deviation

Table 2 - Comparison of mean latencies of waves I, III, V and interpeak intervals I-III, III-V, I-V of the Auditory Brainstem Response $(A B R)$ test in preterm newborns, in both sexes, regarding the adequacy of birth weight

\begin{tabular}{|c|c|c|c|c|c|c|c|c|c|c|}
\hline & \multicolumn{5}{|c|}{ Male/Preterm } & \multicolumn{5}{|c|}{ Female/Preterm } \\
\hline & \multicolumn{2}{|c|}{ SGA $(n=44)$} & \multicolumn{2}{|c|}{ AGA ( $n=44)$} & \multirow{2}{*}{$p$-value } & \multicolumn{2}{|c|}{ SGA (n=44) } & \multicolumn{2}{|c|}{ AGA $(n=44)$} & \multirow{2}{*}{$\begin{array}{c}p \text {-value } \\
p\end{array}$} \\
\hline & Mean & SD & Mean & SD & & Mean & SD & Mean & SD & \\
\hline I & 1.82 & 0.10 & 1.82 & 0.10 & 0.862 & 1.85 & 0.16 & 1.81 & 0.14 & 0.169 \\
\hline III & 4.72 & 0.24 & 4.70 & 0.25 & 0.656 & 4.79 & 0.23 & 4.74 & 0.41 & 0.509 \\
\hline V & 7.24 & 0.35 & 7.29 & 0.35 & 0.556 & 7.27 & 0.45 & 7.27 & 0.42 & 1.000 \\
\hline$|-|||$ & 2.90 & 0.25 & 2.84 & 0.23 & 0.227 & 2.93 & 0.24 & 2.87 & 0.35 & 0.261 \\
\hline III-V & 2.52 & 0.24 & 2.59 & 0.25 & 0.189 & 2.51 & 0.28 & 2.55 & 0.38 & 0.589 \\
\hline I-V & 5.41 & 0.31 & 5.46 & 0.35 & 0.514 & 5.43 & 0.44 & 5.43 & 0.48 & 1.000 \\
\hline
\end{tabular}

SGA: small for gestational age; AGA: appropriate for gestational age; SD: standard-deviation

Table 3 - Comparative study of the mean latencies of waves I, III, V and interpeak intervals I-III, III-V, I-V of the Auditory Brainstem Response $(\mathrm{ABR})$ test in term and preterm neonates, regarding sex

\begin{tabular}{|c|c|c|c|c|c|c|c|c|c|c|}
\hline & \multicolumn{5}{|c|}{ Term } & \multicolumn{5}{|c|}{ Preterm } \\
\hline & \multicolumn{2}{|c|}{ Male $(n=44)$} & \multicolumn{2}{|c|}{ Female $(n=44)$} & \multirow{2}{*}{$p$-value } & \multicolumn{2}{|c|}{ Male $(n=44)$} & \multicolumn{2}{|c|}{ Female $(n=44)$} & \multirow{2}{*}{$p$-value } \\
\hline & Mean & SD & Mean & SD & & Mean & SD & Mean & SD & \\
\hline I & 1.78 & 0.09 & 1.80 & 0.18 & 0.304 & 1.82 & 0.10 & 1.83 & 0.15 & 0.549 \\
\hline III & 4.65 & 0.25 & 4.53 & 0.21 & $<0.001$ & 4.71 & 0.24 & 4.75 & 0.30 & 0.312 \\
\hline V & 7.04 & 0.31 & 6.81 & 0.23 & $<0.001$ & 7.26 & 0.35 & 7.27 & 0.43 & 0.920 \\
\hline$|-|||$ & 2.86 & 0.20 & 2.73 & 0.22 & $<0.001$ & 2.87 & 0.24 & 2.90 & 0.30 & 0.476 \\
\hline III-V & 2.38 & 0.37 & 2.29 & 0.22 & 0.052 & 2.55 & 0.24 & 2.53 & 0.33 & 0.572 \\
\hline I-V & 5.23 & 0.44 & 5.01 & 0.25 & $<0.001$ & 5.43 & 0.33 & 5.43 & 0.46 & 1.000 \\
\hline
\end{tabular}

*Statistically significant values; SD: standard-deviation

Table 4 - Comparative study of mean latencies of waves I, III, V and interpeak intervals I-III, III-V, I-V of the Auditory Brainstem Response $(A B R)$ test, in both sexes, regarding gestational age

\begin{tabular}{|c|c|c|c|c|c|c|c|c|c|c|}
\hline & \multicolumn{5}{|c|}{ Male } & \multicolumn{5}{|c|}{ Female } \\
\hline & \multicolumn{2}{|c|}{ Term $(n=44)$} & \multicolumn{2}{|c|}{ Preterm $(n=44)$} & \multirow{2}{*}{$p$-value } & \multicolumn{2}{|c|}{ Term $(n=44)$} & \multicolumn{2}{|c|}{ Preterm $(n=44)$} & \multirow{2}{*}{$p$-value } \\
\hline & Mean & SD & Mean & SD & & Mean & SD & Mean & SD & \\
\hline I & 1.78 & 0.09 & 1.82 & 0.10 & 0.005 & 1.80 & 0.16 & 1.83 & 0.15 & 0.192 \\
\hline III & 4.65 & 0.25 & 4.71 & 0.25 & 0.115 & 4.52 & 0.21 & 4.76 & 0.33 & $<0.001$ \\
\hline V & 7.04 & 0.31 & 7.26 & 0.35 & $<0.001$ & 6.81 & 0.23 & 7.27 & 0.43 & $<0.001$ \\
\hline$|-|||$ & 2.86 & 0.20 & 2.87 & 0.24 & 0.680 & 2.73 & 0.22 & 2.90 & 0.30 & $<0.001$ \\
\hline III-V & 2.41 & 0.27 & 2.55 & 0.24 & $<0.001$ & 2.29 & 0.22 & 2.53 & 0.33 & $<0.001$ \\
\hline I-V & 5.23 & 0.44 & 5.43 & 0.33 & $<0.001$ & 5.01 & 0.25 & 5.43 & 0.46 & $<0.001$ \\
\hline
\end{tabular}

SD: standard-deviation 
differences. Thus, it was decided to group the ears for the subsequent analyzes.

In the comparative analysis of the ABR results regarding the weight/gestational age ratio (AGA/SGA), no differences were verified for waves I, III, and V and interpeak intervals I-III, III-V, and I-V, both in preterm and term infants, in both sexes (Tables 1 and 2).

It was decided, therefore, to disregard the weight/gestational age to examine the remaining results, grouping children in preterm and term.

In comparing the results of $\mathrm{ABR}$ regarding gender, the comparative study of the mean latencies of waves I, III, V and the interpeak intervals I-III, III-V, I-V of the ABR revealed significant differences, except for wave I $(p=0.304)$, in TNBs, with smaller latencies in the female sex. For PTNBs, no significant differences were observed in the parameters analysed (Table 3).

Regarding female newborns, comparing the TNBs and the PTNBs (Table 4), it was observed that, except for wave I $(p=0.192)$, significant differences were verified in the remaining $A B R$ responses with higher latencies in preterm cases. Regarding the male infants, there were differences in latencies of waves I and V, and in the interpeak intervals III-V and I-V, with more prolonged latencies in preterm infants. Latencies for wave III and interpeak interval I-III did not show differentiation from the statistical perspective.

Graph 1 summarizes the comparative study of ABR responses in the 4 studied groups, comparing the TNBs with the PTNBs, showing better responses in female TNBs, followed by male TNBs, female PTNBs and, finally, male PTNBs.

\section{Discussion}

First, we analyzed the measures of ABR by ear, both in the AGA group (term and preterm) and in the SGA (term and preterm) group in both genders, and no relevant differences were verified. This fact suggests that the maturation of the auditory pathways occurs simultaneously in both ears, regardless of gender, confirming previous results from the literature ${ }^{(20-23)}$. However, this finding was different from studies that have investigated possible mechanisms of interaural asymmetry in newborns through ABR, who reported right ear advantage ${ }^{(24,25)}$.

In the present study, the results of the ABR regarding the classification of the newborn in AGA and SGA did not show relevant differences, suggesting that the classification gestational age/weight had no effect on auditory behavior

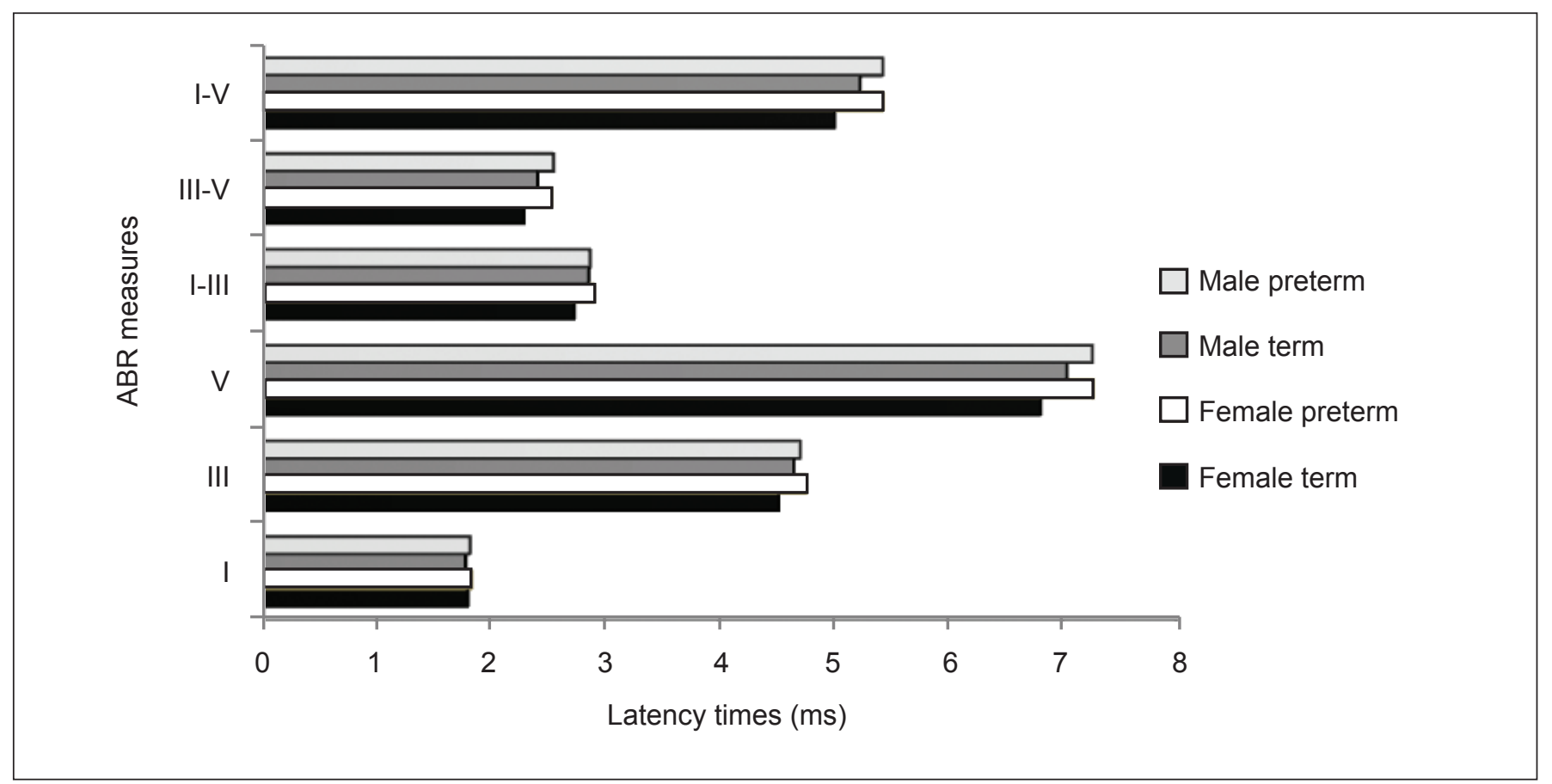

Graph 1 - Comparison of the latencies of waves I, III, V and interpeak intervals I-III, III-V, I-V of the Auditory Brainstem Response $(A B R)$ test, in males and females, in relation to gestational age 
in both genders. However, when analyzing the influence of sex on TNBs, females had shorter latencies of ABR responses. Prospective study, that assessed preterm and term children comparing the absolute latencies of waves I, III and $\mathrm{V}$ and the interpeak intervals of the $\mathrm{ABR}$ in ages from 4, 12 , and 20 months, found no differences regarding sex ${ }^{(26)}$. In a recent study that investigated the auditory behavior of infants through the ABR, no influence of sex was verified when 41 children from 1 to 9 months ${ }^{(27)}$ were analyzed, in disagreement with the present study. It is believed that this discrepancy arises from the difference in the age range covered, once the studied sample included only newborns. On the other hand, a research that evaluated the influence of gender on the ABR obtained significant differences in their results: the male newborns had higher latency and lower amplitudes than the females, for all parameters of the $\mathrm{ABR}^{(28)}$. These findings agree, in part, with those of the study under discussion, because this difference was found in TNBs and in PTNBs, whereas the present study showed difference only among TNBs.

In the group of preterm infants analyzed in this study, the influence of gender was not demonstrated. Other authors came to a similar conclusion while investigating 51 TNBs through ABR, finding that there was no influence of sex on responses ${ }^{(29)}$. This finding must be due to the phenomenon of neurological catch up, characteristic attributed to all preterm infants during the immediate postnatal period, which is independent of gender ${ }^{(29)}$.

\section{References}

1. Goulart AL. Caracterização da população neonatal. In: Kopelman BI, Santos AM, Goulart AL, Almeida MF, Miyoshi MH, Guinsburg R, editors. Diagnóstico e tratamento em neonatologia. São Paulo: Atheneu; 2004. p. 3-10.

2. Rooney R, Hay D, Levy F. Small for gestational age as a predictor of behavioral and learning problems in twins. Twin Res 2003;6:46-54.

3. Mello BB, Gonçalves VM, Souza EA. Behavior of full term infants small for gestational age in the first three months of life. Arq Neuropsiquiatr 2004;62:1046-51.

4. Alexander GR, Himes JH, Kaufman RB, Mor J, Kogan M. A United States national reference for fetal growth. Obstet Gynecol 1996;87:163-8.

5. Figueras F, Oros D, Cruz-Martinez R, Padilla N, Hernandez-Andrade E, Botet $\mathrm{F}$ et al. Neurobehavior in term, small-for-gestational age infants with normal placental function. Pediatrics 2009;124:e934-41.

6. Pereira MR, Funayama CA. Evaluation of some aspects of the acquisition and development of language in pre-term born children. Arq Neuropsiquiatr 2004;62:641-8.

7. Goto MM, Gonçalves VM, Netto AA, Morcillo AM, Moura-Ribeiro MV. Neurodevelopment of full-term small-for-gestacional age infants in the second month of life. Arq Neuropsiquiatr 2005;63:75-82.

8. Sleifer P, da Costa SS, Cóser PL, Goldani MZ, Dornelles C, Weiss K. Auditory brainstem response in premature and full-term children. Int J Pediatr Otorhinolaryngol 2007;71:1449-56.
When analyzing females regarding the gestational age, it was verified that, except for wave I, the absolute latencies and interpeak intervals of the ABR showed statistical significance, with higher latencies in preterm infants. Such findings agree with the literature as to the fact that wave I is almost mature at birth, even in PTNBs. These findings are also in line with studies that mention increased latencies in ABR responses in PTNBs when compared to TNBs, due to immaturity, possibly because the myelination of neuronal fibers, responsible for triggering the potentials, is incomplete ${ }^{(10-12,14,15)}$.

The premature infants presented absolute latencies from wave III and larger interpeak intervals than the TNBs. Nevertheless, authors suggest neurophysiological changes after birth in term and preterm newborns, without their being considered dysfunctional ${ }^{(30)}$.

This study concluded that gender exerts significant influence on the ABR of TNBs, with shorter responses in females. $A B R$ responses in preterm infants differ significantly from the responses in term infants. Both variables should be considered (sex and gestational age) in clinical analysis. On the other hand, the weight/gestational age ratio did not affect the responses of this potential. However, it should be emphasized that, because the SGA group is a very heterogeneous group, that might have suffered injuries at different times of intrauterine life and presents diverse auditory behavior, more detailed studies are recommended in order to show a more specific overview for each situation involved.

9. Jiang ZD, Brosi DM, Wu YY, Wilkinson AR. Relative maturation of peripheral and central regions of the human brainstem from preterm to term and the influence of preterm birth. Pediatr Res 2009;65:657-62.

10. Jiang ZD, Zhou Y, Ping LL, Wilkinson AR. Brainstem auditory response findings in late preterm infants in neonatal intensive care unit. Acta Paediatr 2011;100:e51-4.

11. American Academy of Pediatrics; Joint Committee on Infant Hearing. Year 2007 position statement: principles and guidelines for early hearing detection and intervention programs. Pediatrics 2007;120:898-921.

12. Casali RL, Santos MF. Auditory brainstem evoked response: response patterns of full-term and premature infants. Braz J Otorhinolaryngol 2010;76:729-38.

13. Cavalcante JM. Registro dos potenciais evocados auditivos de tronco encefálico por estímulos click e tone burst em recém-nascidos a termo e pré-termo [tese de mestrado]. Ribeirão Preto (SP): USP; 2010.

14. Ferraro JA, Durrant J. Potenciais auditivos evocados: visão geral e princípios básicos. In: Katz J, editor. Tratado de audiologia clínica. $4^{\text {th }}$ ed. São Paulo: Manole; 1999. p. 228-81.

15. Pedriali IV, Kozlowski L. The influence of abr clik intensity and rate in adults with normal hearing. Arq Int Otorrinolaringol 2006;10:105-13.

16. Angrisani RM, de Azevedo MF, Carvallo RM, Diniz EM, Matas CG. Electrophysiological study of hearing in full-term small-for-gestational-age newborns. J Soc Bras Fonoaudiol 2012;24:162-7. 
17. Autoria não referida. The incidence of low birth weight: a critical review of available information. World Health Stat Q 1980;33:197-224.

18. Margolis RH, Popelka GR. Static and dynamic acoustic impedance measurements in infants ears. J Speech Hear Res 1975;18:435-43.

19. Jasper $\mathrm{HH}$. The ten-twenty electrode system of the International Federation. Electroencephalogr Clin Neurophysiol 1958;10:371-5.

20. Guilhoto LM, Quintal VS, da Costa MT. Brainstem auditory evoked response in normal term neonates. Arq Neuropsiquiatr 2003;61:906-8.

21. Amorim RB, Agostinho-Pesse RS, Alvarenga KF. The maturational process of the auditory system in the first year of life characterized by brainstem auditory evoked potentials. J Appl Oral Sci 2009;17:57-62.

22. Sleifer P, da Costa SS, Cóser PL, Goldani MZ, Dornelles C, Weiss K. Auditory brainstem response in premature e full-term children. Int $\mathrm{J}$ Pediatr Otorhinolaryngol 2007;71:1449-56.

23. Fichino SN, Lewis DR, Fávero ML. Electrophysiologic threshold study in air and bone conduction in children with 2 months or less age. Rev Bras Otorrinolaringol 2007;73:251-6.
24. SiningerYS, Cone-Wesson B. Lateral asymmetry in the ABR of neonates: evidence and mechanisms. Hear Res 2006;212:203-11.

25. Eldredge L, Salamy A. Functional auditory development in preterm and full term infants. Early Hum Dev 1996;45:215-8.

26. Sleifer P, da Costa SS, Cóser PL, Goldani MZ, Dornelles C, Weiss K. Auditory brainstem response in premature and full-term children. Int J Pediatr Otohinolaryngol 2007;71:1449-56.

27. Romero AC, Delecrode CR, Cardoso AC, Frizzo AC. Potencial evocado auditivo de tronco encefálico em crianças encaminhadas de um programa de triagem auditiva neonatal. Rev Bras Saude Mater Infant 2012;12:145-53.

28. Li M, Zhu L, Mai X, Shao J, Lozoff B, Zhao Z et al. Sex and gestational age effects on auditory brainstem responses in preterm and term infants. Early Hum Dev 2013;89:43-8.

29. Kohelet D, Arbel E, Goldberg M, Arlazzoroff A. Intrauterine growth retardation and brainstem auditory-evoked response in preterm infants. Acta Paediatr 2000;89:73-6.

30. Chiang MC, Chou YH, Wang PJ. Auditory brainstem evoked potentials in healthy full-term and pre-term infants. Chang Gung Med J 2001;24:557-62. 